\title{
Evolutionary morphology of the antennal heart in stick and leaf insects (Phasmatodea) and webspinners (Embioptera) (Insecta: Eukinolabia)
}

\author{
Benjamin Wipfler ${ }^{1}$ (D) Sven Bradler ${ }^{2} \cdot$ Sebastian Büsse ${ }^{3} \cdot$ Jörg Hammel $^{4} \cdot$ Bernd R. Müller $^{5} \cdot$ Günther Pass $^{6}$
}

Received: 28 January 2021 / Revised: 15 April 2021 / Accepted: 27 April 2021 / Published online: 1 June 2021

(C) The Author(s) 2021

\begin{abstract}
The morphology of the antennal hearts in the head of Phasmatodea and Embioptera was investigated with particular reference to phylogenetically relevant key taxa. The antennal circulatory organs of all examined species have the same basic construction: they consist of antennal vessels that are connected to ampullae located in the head near the antenna base. The ampullae are pulsatile due to associated muscles, but the points of attachment differ between the species studied. All examined Phasmatodea species have a Musculus (M.) interampullaris which extends between the two ampullae plus a M. ampulloaorticus that runs from the ampullae to the anterior end of the aorta; upon contraction, all these muscles dilate the lumina of both ampullae at the same time. In Embioptera, only the australembiid Metoligotoma has an M. interampullaris. All other studied webspinners instead have a M. ampullofrontalis which extends between the ampullae and the frontal region of the head capsule; these species do not have M. ampulloaorticus. Outgroup comparison indicates that an antennal heart with a M. interampullaris is the plesiomorphic character state among Embioptera and the likely ground pattern of the taxon Eukinolabia. Antennal hearts with a M. ampullofrontalis represent a derived condition that occurs among insects only in some embiopterans. These findings help to further clarify the controversially discussed internal phylogeny of webspinners by supporting the view that Australembiidae are the sister group of the remaining Embioptera.
\end{abstract}

Keywords Circulatory organ $\cdot$ Phylogeny $\cdot$ Sister group $\cdot$ Polyneoptera $\cdot$ Timema $\cdot$ Metoligotoma $\cdot$ Australembiidae $\cdot$ Clothodidae

Benjamin Wipfler

benjamin.wipfler@leibniz-zfmk.de

1 Morphologielabor, Zoologisches Forschungsmuseum Alexander Koenig, Bonn, Germany

2 Animal Evolution and Biodiversity, Georg-August-Universität Göttingen, Göttingen, Germany

3 Functional Morphology and Biomechanics, Institute of Zoology, Kiel University, Kiel, Germany

4 Institute of Materials Physics, Helmholtz-Zentrum-Geesthac ht, 21502 Geesthacht, Germany

5 Department of Non-Destructive Testing, Bundesanstalt für Materialforschung und -prüfung, Berlin, Germany

6 Department für Evolutionsbiologie, Universität Wien, Vienna, Austria

\section{Introduction}

The circulatory system of insects serves a multitude of vital transport functions within the body, including those of molecules, hemocytes, or thermal energy (reviews: Hertel and Pass 2002; Hillyer and Pass 2020; Jones 1977; Miller 1985; Miller and Pass 2009; Wirkner and Richter 2010; Wirkner et al. 2013). For this purpose, the hemolymph, which moves freely between the inner organs, is propelled through the central body cavity by rhythmic contractions of the dorsal vessel (often simply called "the heart"). However, the pumping activity of this muscular tube usually cannot circulate the hemolymph in longer hollow body appendages, such as antennae, wings, legs, cerci, and the terminal filament (Pass 1998, 2000). Only a few primarily wingless hexapods have arterial vessels that connect to the dorsal vessel and supply some of these appendages (Gereben-Krenn and Pass 1999; Pass 1991). In the course of hexapod evolution, these arteries became disconnected from the dorsal vessel 
or were reduced and independent accessory circulatory organs evolved to ensure hemolymph supply of the various body appendages. These can be either simple guiding structures that passively lead the hemolymph flow through these appendages, or accessory pulsatile organs which function as autonomous auxiliary hearts that actively pump hemolymph through these appendages (reviews: Pass 1998, 2000; Pass et al. 2006; Wirkner et al. 2013). Many of these circulatory organs are evolutionary novelties of pterygote insects, which make them prime examples to investigate the poorly understood topic of the origin of novel organs (Pass 2000; Pass et al. 2015).

Among the accessory pulsatile organs, the antennal hearts have received most attention so far (Baum et al. 2007; Hertel et al. 1985, 1997, 2012; Hertel and Pass 2002; Pass 1980, 1988, 1991; Pass et al. 1988; Pawlowa 1895; Raina et al. 2003; Sun and Schmidt 1997; Wipfler and Pass 2014). They are vital for the hemolymph supply of the numerous sensory organs located in the antennae (review: Zacharuk 1985). In addition, they may serve as neurohaemal organs which release hormones that are likely of relevance for the control of the antennal sensilla (Antemann et al. 2018; Pass 1985, 1988; Pass et al. 1988). Remarkably, the antennal circulatory organs exhibit an unusual disparity in their constructional morphology within Insecta, which makes them informative traits for phylogenetic research (Pass et al. 2006). A good example of this are the polyneopteran insects whose antennal hearts can have very different functional morphologies (Pass 1991). Within this group, three fundamentally different types can be found: I) the hemolymph can be guided into the ampullae and thus into the antennal vessel via non-pulsatile control of the cephalic hemolymph flow with septae as in some stoneflies (Pass 1991), II) active pulsatile dilation of the ampullae with several different associated muscles (in most polyneopterans: Pass 1991; Wipfler et al. 2011) or III) by compression of the ampullae by musculature in earwigs (Pass 1988). Each of these functional principles, especially the dilation of the ampulla has several morphologically strongly differing subtypes which involve a total of six different muscles (Pass 1991; Wipfler et al. 2011). The phylogenetic relationships of the high-rank polyneopteran taxa (which are classified as orders in traditional zoological systematics) remained the most puzzling part in insect phylogeny and were therefore represented long as a large unsolved polytomy (review: Kristensen 1991). Recently, however, a well-supported cladogram based on phylogenomic data has been established and phylogenies for most subgroups were provided (Misof et al. 2014; Wipfler et al. 2019). These cladograms allow for the first time a sound evolutionary interpretation of characters among the major groups of Polyneoptera. Phasmatodea, and Embioptera, which are the focus of the present study, are groups that have been discussed controversially with regard to their phylogenetic position. Embioptera undoubtedly represent a monophyletic taxon (Kristensen 1991; Szumik et al. 2008), especially in view of unique morphological and behavioural traits. The embiopteran life is strongly dependent on silk in every postembryonic stage. These subsocial insects mainly use silk to build tube-like domiciles for themselves and their offspring; protecting them against predators and environmental influences (Edgerly 1994, 1997; Edgerly et al. 2002; Ross 2000; Stokes et al. 2018). The silk is produced in glands in their front legs (Fig. 1; spinning tarsus; Barth 1954; Büsse et al. 2015) using a "passive" pressure-induced silk spinning mechanism (Büsse et al. 2019) and a complex spinning behaviour (Edgerly et al. 2002, 2012). However, regarding their phylogenetic position within Polyneoptera, a number of different taxa were considered as closest relatives: Hennig (1969) considered a clade comprising all polyneopterans except Plecoptera and Zoraptera as potential sister group, Rähle (1970) Phasmatodea, Haas and Kukalová-Peck (2001) Plecoptera, Grimaldi and Engel (2005) Zoraptera (with Plecoptera as closest related lineage), and in the comprehensive cladistic analysis of Beutel and Gorb (2006), Embioptera were the sister to all Neoptera except Plecoptera. The same is true for phasmids: they are generally viewed as monophylum because of some unique morphological and life-history traits. Phasmids are known to be exclusively phytophagous insects, which are highly adapted to their respective habitat - they are imitating twigs or leaves for camouflage (Fig. 1; cf. Bradler 2009). This group was undergoing a fast radiation (Bradler et al. 2015), causing different lineages of phasmids inhabiting similar habitats, in an almost worldwide distribution, representing similar adaptations (cf. Buckley et al. 2009; Simon et al. 2019). These convergent adaptations are for example specialized egg deposition modes (Bradler et al. 2015; Goldberg et al. 2015; O'Hanlon et al. 2020), the loss of forewings (respectively, rudimentary forewings; cf. Zeng et al. 2020), specialized substrate-specific attachment microstructures on the tarsi (Büscher et al. 2018a, b), or the general shape of the phasmids body (cf. Buckley et al. 2009). The phylogenetic results for Phasmatodea within the Polyneoptera are, however, similarly confusing as for Embioptera, and every orthopteroid insect order has already been discussed as a potential sister group (review: Friedemann et al. 2012). In view of this controversial situation, great hopes were placed in molecular approaches. Terry and Whiting (2005) recovered Embioptera and Phasmatodea in their multigene study as sister taxa and named the clade Eukinolabia. This relationship was later supported by additional molecular (Ishiwata et al. 2011; Letsch and Simon 2013; Letsch et al. 2012; Misof et al. 2014; Simon et al. 2019; Whiting 
Fig. 1 Habitus in dorsal view of a Sipyloidea sipylus (adultus) and b Antipaluria urichi (subadult male). an antennae, ce compound eye, $s p$ spinning tarsus. Scale bars: $2.5 \mathrm{~mm}$

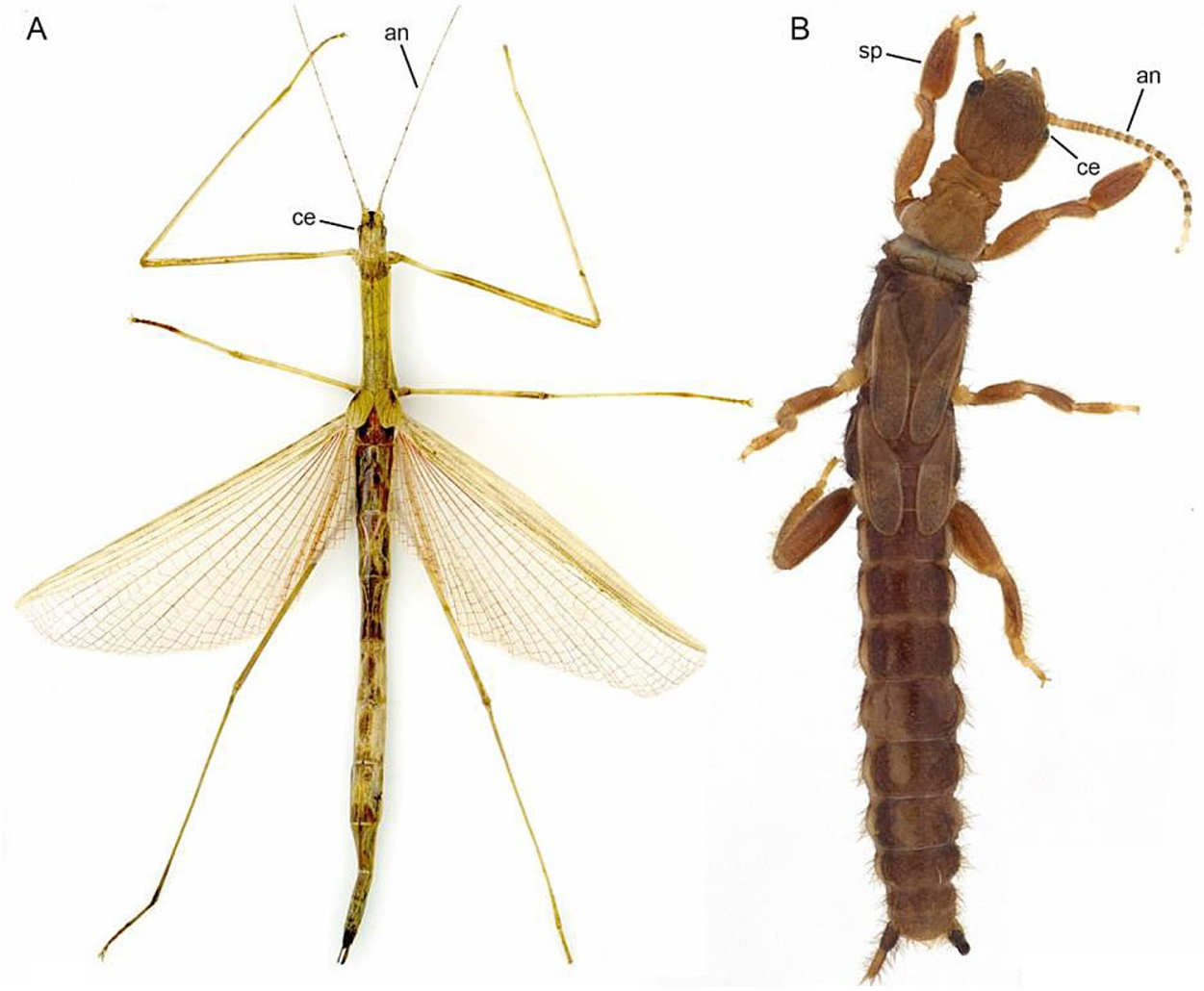

et al. 2003; Wipfler et al. 2019) and morphological studies (Friedemann et al. 2012; Matsumura et al. 2015; Wipfler et al. 2011). In summary, today, the Eukinolabia with Embioptera and Phasmatodea as sister groups can be regarded as a well-supported hypothesis.

Against this background, the antennal hearts are of particular interest, since Embioptera and Phasmatodea have different construction types of this organ according to previous studies (Pass 1991). However, so far, only a few species which represent more recent splits in the trees of Phasmatodea and Embioptera have been investigated. Aim of the present study is to enlarge the data set and to include so-called key species, which represent early split lineages of these two polyneopteran groups.

\section{Materials and methods}

Table 1 gives an overview of the investigated species of Phasmatodea and Embioptera. The specimens were all adults and fixed in either $80 \%$ ethanol or alcoholic Bouin ("Dubosq-Brasil" mixture). For the sake of simplicity, the full scientific name of the species is given only when mentioned for the first time, later only generic names are used. For $\mu$-computed tomography ( $\mu$-CT) scanning, the samples were critical point dried (Emitech K850 critical point dryer) and mounted onto specific specimen holders (scanning facilities and scan parameters listed in Table 1). The data were imported into Visage Imaging Amira 5.2.2 (Thermofisher, Waltham, USA) to perform segmentation. The final images are a combination of volume rendering (module "volren" in Amira) and surface rendering (module "surfacegen" in Amira).

The cutting parameters and embedding media for the serial sections are listed in Table 1. The sections were photographed in digitized form with an Axioskop microscope (Carl Zeiss AG, Jena, Germany) with a PixeLink PL-B686 camera (PixeLink, Ottawa, Canada) using the software PixeLink CaptureOEM 7.12 (2008). For z-stacked photography (Fig. 1), we used a custom-made 3D-printed illumination dome system (Bäumler et al. 2020) and an Olympus OMD 10mkII digital camera (Olympus K.K., Tokyo, Japan), equipped with a Leica $45 \mathrm{~mm}$ macro lens (Leica Camera AG, Wetzlar, Germany). The images were subsequently processed in Affinity Photo and Affinity Designer (Serif Ltd, Nottingham, United Kingdom). The histological sections and the $\mu$-CT scans are deposited in the collection of the Alexander Koenig Museum, Bonn, Germany and can be requested from the first author. The descriptions are based on the morphological terminology of Seifert (1970), and the muscle terminology follows Wipfler et al. (2011). 
Table 1 Taxon sampling and applied methods

\begin{tabular}{|c|c|c|c|c|c|c|c|c|}
\hline \multirow[t]{2}{*}{ Order/family } & \multirow[t]{2}{*}{ Species } & \multirow[t]{2}{*}{ Origin } & \multicolumn{3}{|c|}{ Histological sections } & \multicolumn{3}{|l|}{$\mu-\mathrm{CT}$} \\
\hline & & & Thickness & Plane & Staining & Facility & $\begin{array}{l}\text { Spatial res. } \\
(\mu \mathrm{m})\end{array}$ & Rot steps $\left({ }^{\circ}\right)$ \\
\hline $\begin{array}{l}\text { Phasmatodea/ } \\
\text { Timematidae }\end{array}$ & Timema sp. & California, USA & $10 \mu \mathrm{m}$ & Cross section & Toluidine blue & DESY & 3.2 & 0.25 \\
\hline $\begin{array}{l}\text { Phasmatodea/ } \\
\text { Lonchodidae }\end{array}$ & $\begin{array}{l}\text { Sipyloidea sipylus } \\
\text { (Westwood } \\
\text { 1859) }\end{array}$ & Madagascar & - & - & - & BESSY & 2.486 & 0.1 \\
\hline $\begin{array}{l}\text { Phasmatodea/ } \\
\text { Phylliidae }\end{array}$ & $\begin{array}{l}\text { Phyllium philip- } \\
\text { pinicum Henne- } \\
\text { mann, Conle, } \\
\text { Gottardo and } \\
\text { Bresseel } 2009\end{array}$ & $\begin{array}{l}\text { Luzon, Philip- } \\
\text { pines }\end{array}$ & - & - & - & BESSY & 2.486 & 0.09 \\
\hline $\begin{array}{l}\text { Phasmatodea/ } \\
\text { Phasmatidae }\end{array}$ & $\begin{array}{l}\text { Medauroidea } \\
\text { extradentata } \\
\text { (Brunner von } \\
\text { Wattenwyl } \\
\text { 1907) }\end{array}$ & Annam, Vietnam & $10 \mu \mathrm{m}$ & Cross section & Azan & - & - & - \\
\hline $\begin{array}{l}\text { Embioptera / } \\
\text { Embiidae }\end{array}$ & $\begin{array}{l}\text { Embia contorta } \\
\text { Ross } 1966\end{array}$ & India & $1 \mu \mathrm{m}$ & Cross section & Azan & - & - & - \\
\hline $\begin{array}{l}\text { Embioptera/Oli- } \\
\text { gotomidae }\end{array}$ & $\begin{array}{c}\text { Oligotoma nigra } \\
\text { Hagen } 1885\end{array}$ & Algeria & $1 \mu \mathrm{m}$ & Cross section & Azan & - & - & - \\
\hline $\begin{array}{l}\text { Embioptera/Aus- } \\
\text { tralembiidae }\end{array}$ & Metoligotoma sp. & Australia & - & - & - & DESY & 1.74 & 0.25 \\
\hline $\begin{array}{l}\text { Embioptera/ } \\
\text { Clothodidae }\end{array}$ & $\begin{array}{r}\text { Antipaluria urichi } \\
\text { (Saussure 1896) }\end{array}$ & $\begin{array}{l}\text { Trinidad and } \\
\text { Tobago }\end{array}$ & - & - & - & ZFMK & 2.00 & 0.06 \\
\hline
\end{tabular}

BESSY BAM-Line of the Berliner Elektronensynchrotron; DESY Beamline P07 at Petra IV at the Deutsches Elektronen-Synchrotron

\section{Results}

In all studied species, the antennal hearts are autonomous circulatory organs that function independently from the dorsal vessel. The anterior end of the aorta is located behind the brain and the outpouring hemolymph flows through a kind of channel, formed by the brain, the circumesophageal connectives, and the pharynx, into the hemocoelic space in front of the supraesophageal ganglion. This is where the antennal heart is attached to the frontal cuticle.

The antennal hearts of all studied species consist of thinwalled ampullary formations that are attached to the frontal cuticle close to each antenna base. The ampullae are joined to vessels which extend into the antennae. They have valved ostia through which hemolymph can enter from the hemocoelic space in front of the supraesophageal ganglion. The ampullae are pulsatile due to associated pumping muscles, which differ in their attachment points between the species studied (details are given in the following chapters). The muscles are all dilators which enlarge the ampulla lumen upon contraction. Hemolymph can then enter the ampullae through valved ostia from the hemocoelic space in front of the supraesophageal ganglion. After relaxation of the dilator muscles, the ampullae collapse due to the elasticity of the wall. Thereby hemolymph is forced through the antennal vessels up to the tip of the antennae, where it pours out and returns back in the hemocoel of the antennae into the head capsule (see Pass 1985; Hertel et al. 1985; Boppana and Hillyer 2014).

\section{Phasmatodea}

In Timema sp., the ampullae are located mesally to the antennae. They are attached with their outer wall directly to the frontal cuticle and also by small connective tissue strands running laterally (Fig. 2a, b). The antennal vessels have a uniform wall of a single-layer epithelium and extend from the ampullae straight into the antennae. A Musculus (M.) interampullaris (0ah1, Figs. 2a, b and 3a, c) and a paired $M$. ampulloaorticus (0ah2, Figs. 2a, b and 3a, c) attach mesally on each ampulla. Near the mid-sagittal plane, the latter separate from the former, unite mesally and continue as very delicate muscle strands (Fig. 2a) that run underneath the supraesophageal ganglion backwards to the anterior end of the aorta (Fig. 3a). There, they are attached to the upper part of the aortic tube. From a dorsal view, the M. interampullaris is not stretched straight between the two ampullae, but held in a U-shaped position by the M. ampulloaorticus. Due to this specific anatomical arrangement, the expansion of the ampullae is apparently maximized during contraction of 
Fig. 2 Horizontal semi-thin sections through the head showing the antennal circulatory organs. a, b Timema sp. (Phasmatodea), composite image of two sections from different cutting levels. Antennal heart with M. interampullaris. Left section shows branching off the M. ampulloaorticus. c, d Oligotoma nigra (Embioptera), composite image of two sections from different cutting levels. Left hand antennal heart with $\mathrm{M}$. ampullofrontalis; the right picture shows the origin of $\mathrm{M}$. ampullofrontalis at the frontal cuticle. Oahl M. interampullaris, Oah2 M. ampulloaorticus, Oah4 M. ampullofrontalis anterior, Oah4or origin of M. ampullofrontalis anterior, Oan1 M. tentorioscapalis anterior, Obu2 M. frontobuccalis anterior, Obu3 M. frontobuccalis posterior, Ohyl M. frontooralis, Olb1 M. frontolabralis, Olb2 M. frontoepipharyngalis, am antennal ampulla, ata anterior antennal arms, $a v$ antennal vessel, $f_{c}$ frontal cuticle, $f g$ frontal ganglion, $s c$ scapus, $s o g$ supraesophageal ganglion. Scale bars: $1 \mathrm{~mm}$

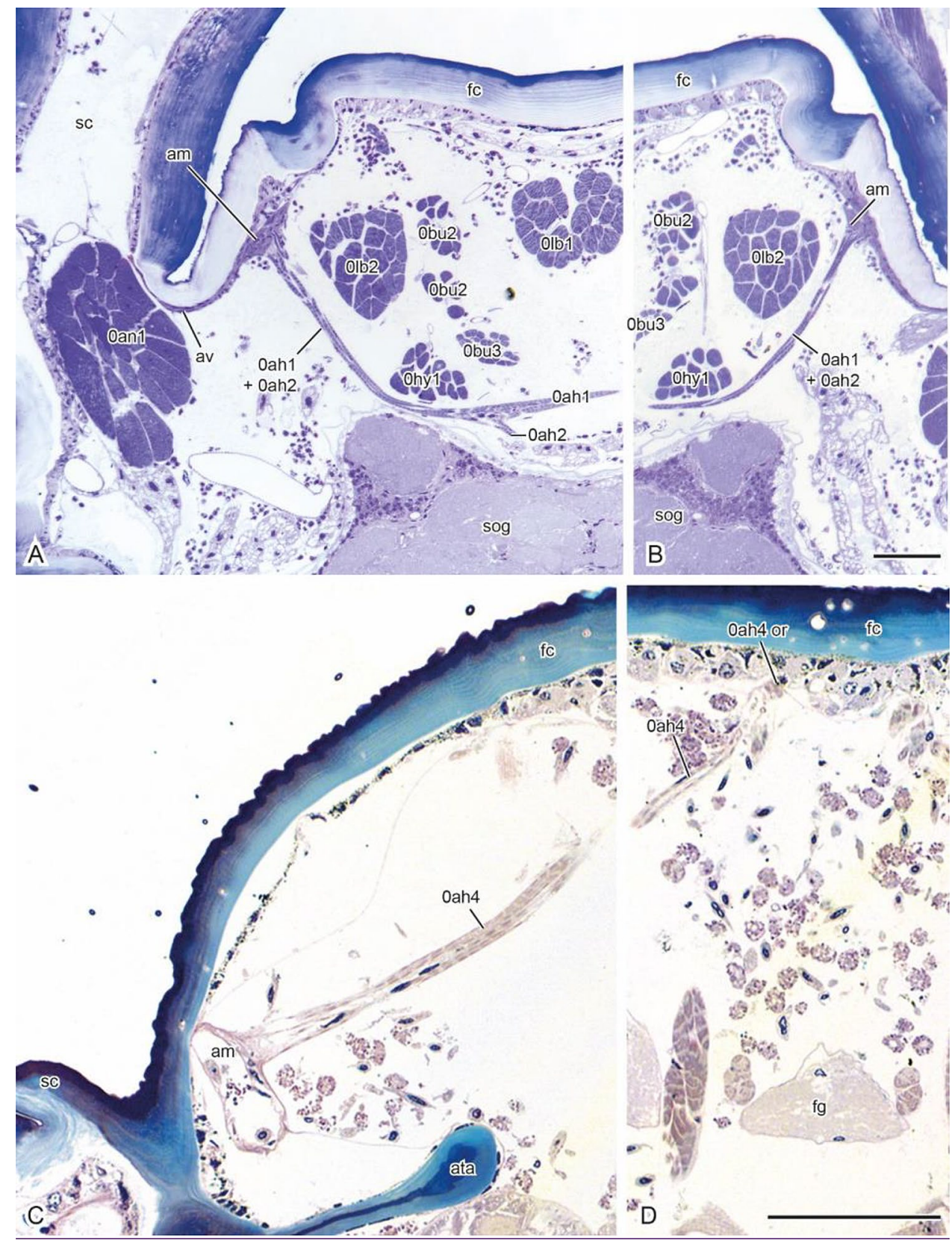

these muscles. There are no connective tissue bands extending between the ampullae and the supraesophageal ganglion.

In Phyllium philippinicum (Fig. 3b, d), the head is much narrower and the two antenna bases are closer together. Accordingly, the proportions of the individual parts of the antennal heart are different. The configuration of the muscles associated with the ampullae however is the same as in Timema: There is a M. interampullaris and a M. ampulloaorticus. The same condition holds also true for the examined species Medauroidea extradentata and Sipyloidea sipylus (Fig. 1).

\section{Embioptera}

In Metoligotoma sp., (Fig. 4a, c), the antennal ampullae are positioned mesally of the antennal sockets, in the anterior corner between the anterior tentorial arms and the head capsule. They are connected by a thin M. interampullaris (0ah1, 
Fig. 3 Three-dimensional visualisation of the transparent head capsule with selected inner organs of Phasmatodea. The antennal heart consists of paired ampullae to which dilator muscles (M. interampullaris and M. ampulloaorticus) are associated. a+c Timema sp.; b+d Phyllium philippinicum. a and b dorsal view; c and $\mathbf{d}$ frontal view. Cuticle made transparent. Blue: ampullae of antennal heart and aorta; orange: antennal heart muscles: dark grey: nervous system; green: digestive tract. Oah1 M. interampullaris, Oah2 M. ampulloaorticus, am antennal ampulla, $a o$ aorta, $a v$ antennal vessel, ce compound eye, $f o$ foramen occipitale, it intestinal tract, $s g$ subesophageal ganglion; sog supraesophageal ganglion

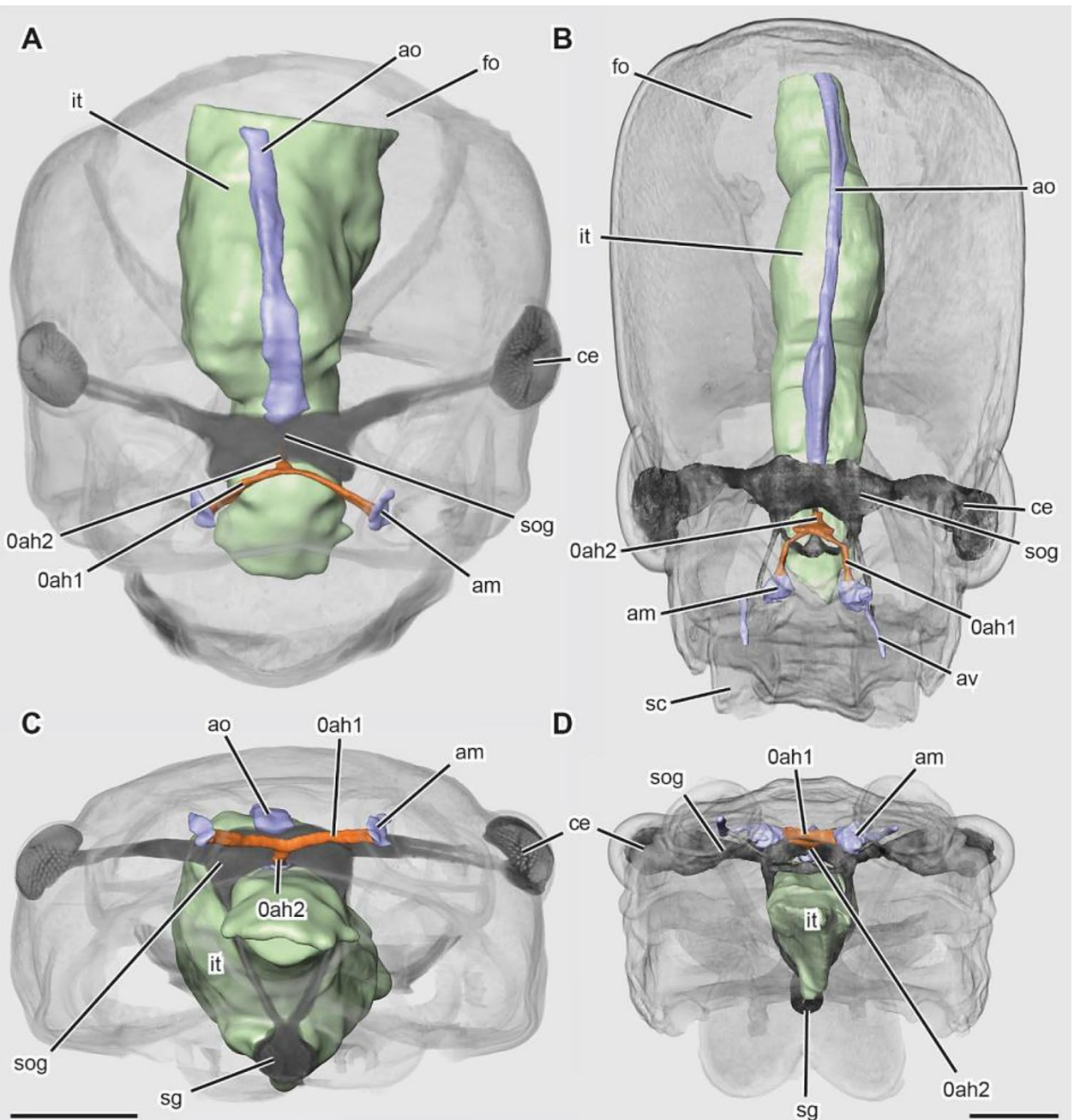

Fig. 4a, c) that extends not straight between the ampullae, but is U-shaped from the dorsal perspective (Fig. 4a). This shape of the interampullary muscle can only be explained by a few thin muscle fibers that branch off from the central area of the latter and run backwards and thus act as a counter-bearing when the interampullary muscle contracts; their second attachment point could not be unambiguously identified in the CT scan. The antennal vessel wall has a uniform structure with a single-layer epithelium along its entire length.

In Oligotoma nigra (Figs. 2c, d and 4b, d), the ampullae and the antennal vessels have exactly the same position and appearance as in Megoligotoma. The most important difference concerns the associated dilator muscle. In Oligotoma, each ampulla has its own muscle which is attached on the one end with the inner wall of the ampullae, the other attachment is mesally at the frontal cuticle (fc in Fig. 2c, d). The attachment sites of this paired M. ampullofrontalis anterior (0ah4, Figs. 2c, d and 4b, d) at the frontal cuticle (0ah4 or, Fig. 1d) are close but well separated from each other. The same condition of the antennal heart as in Oligotoma with a paired M. ampullofrontalis anterior was found in the examined Embia contorta and Antipaluria urichi (Fig. 1). In contrast to all other studied embiopterans, the ampullae of Embia contorta are connected to the supraesophageal ganglion by thin bands of tissue containing fibrous material and long ovoid nuclei.

\section{Discussion}

So far, only a few studies addressed the antennal heart morphology in phasmatodeans. Scholl (1969) and Pass (1991) studied Carausius (the first C. morosus, the latter unidentified $C$. sp.). In addition, there are some incomplete and unillustrated descriptions of the antennal heart muscles of Phyllium philippinicum (referred to as Ph. siccifolium), Sipyloidea sipylus (both Friedemann et al. 2012) and Agathemera crassa (Wipfler et al. 2011). These descriptions are consistent with respect to the presence of paired ampullae with antennal vessels having a uniform wall and two muscles associated with the antennal heart ampulla: The unpaired 
Fig. 4 Three-dimensional visualisation of the transparent head capsule with selected inner organs of Embioptera. The antennal heart consists of paired ampullae to which dilator muscles (M. interampullaris and M. ampullofrontalis anterior) are associated. $\mathbf{a}+\mathbf{c}$ Metoligotoma sp.; b+d Antipaluria urichi. $\mathbf{a}$ and $\mathbf{b}$ dorsal view; $\mathbf{c}$ and $\mathbf{d}$ frontal view. Cuticle made transparent. Blue: circulatory system; dark grey: nervous system; green: digestive system; orange: musculature. Oah1 M. interampullaris, Oah4 M. ampullofrontalis anterior, am antennal ampulla, ao aorta, ce compound eye, fo foramen occipital, it intestinal tract, $s c$ scapus, $s g$ subesophageal ganglion; sog supraesophageal ganglion

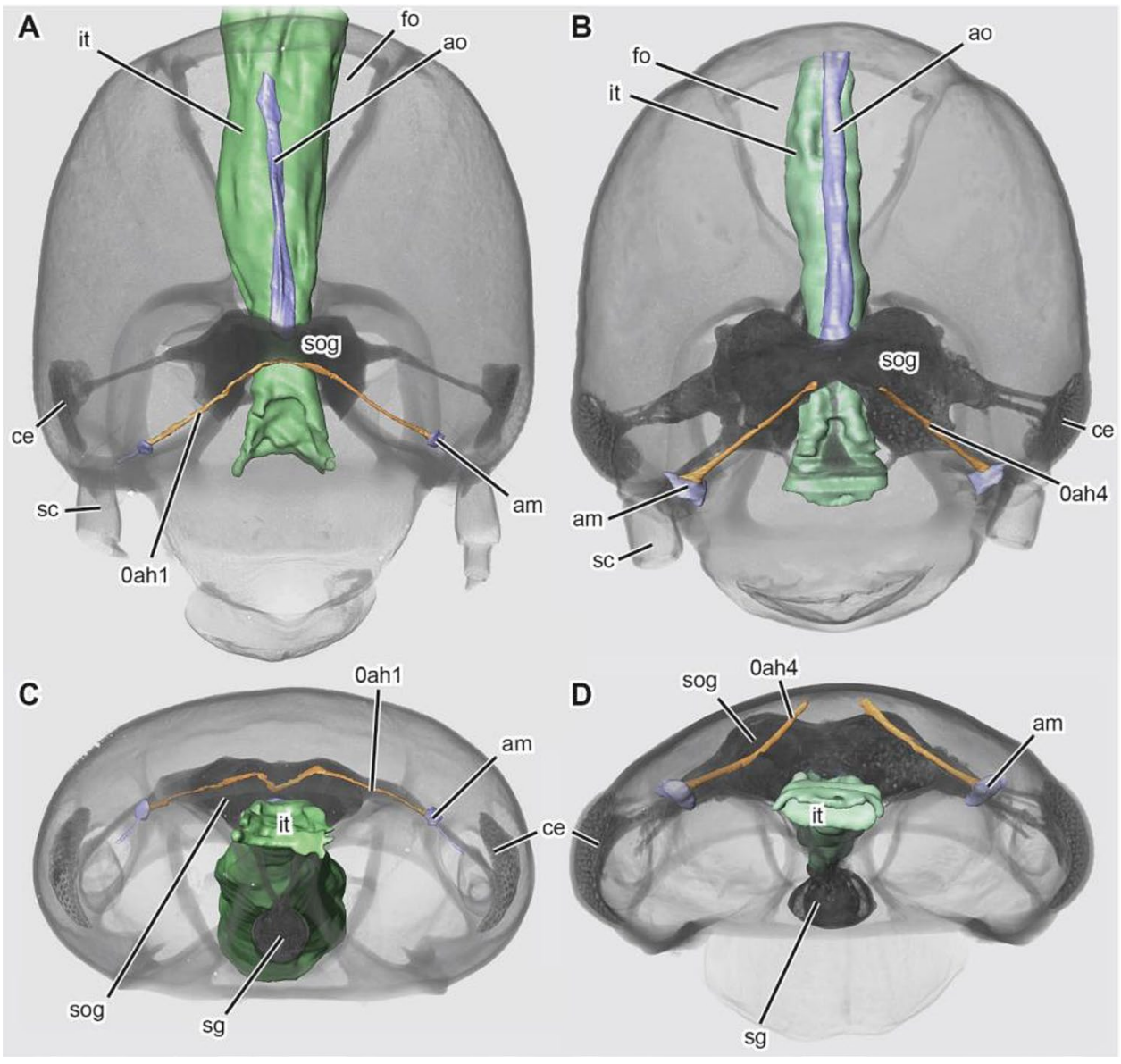

M. interampullaris (0ah1) that interconnects the antennal ampullae and the M. ampulloaorticus (0ah2) that runs from the antennal ampullae towards the anterior end of the aorta. Our investigations confirm that this situation is also present in Timema, Medauroidea, Sipyloidea, and Phyllium. In view of this congruence and the well-supported sister group relationship between Timema and the remaining phasmatodeans (e.g. Ishiwata et al. 2011; Simon et al. 2019), the anatomical condition described can be regarded as the ground pattern of this organ for Phasmatodea.

With regard to Embioptera, the first description of an antennal circulatory organ goes back to Rähle (1970), who claimed that in Embia ramburi, the aorta is connected to each antennal ampulla by a thin vessel which, according to his description, appeared always collapsed in the histological sections. Pass (1991) investigated two species of Embia (E. contorta and E. tyrrhenica) and Haploembia solieri, and found a consistent configuration of the antennal heart in all these species: a thin muscle, the M. ampullofrontalis anterior (0ah4), is attached to the ampulla wall and on the other end at the medial part of the frontal cuticle. The results for Oligotoma and Antipaluria in this study are fully in agreement with the latter description and we again confirm the assumption of Pass (1991) that Rähle
(1970) probably misinterpreted these muscles as collapsed vessels. The re-investigation of Embia contorta revealed an additional band of connective tissue containing fibrous material and long ovoid nuclei between the ampulla and the supraesophageal ganglion, which was not mentioned by Pass (1991). Among insects, similar structures containing fibrous material and long ovoid nuclei are only described for Xenonomia (= Grylloblattodea and Mantophasmatodea) (Wipfler et al. 2011). Although this taxon is considered to represent the sistergroup to Eukinolabia (Misof et al. 2014; Wipfler et al. 2019), a homology between these structures in Embia and Xenonomia would presuppose multiple losses in Embioptera and Phasmatodea, but further research is required to definitely solve this issue. The situation in Metoligotoma is in agreement with the other examined webspinners concerning the position of the ampulla and the uniform antennal vessel wall. However, the muscular equipment is different: the M. ampullofrontalis anterior (0ah4) is missing, and instead, there is a M. interampullaris (0ah1). The few thin muscle fibers that branch off from central area of the $\mathrm{M}$. interampullaris and run backwards likely act as counter-bearing to hold the latter in a U-shaped position. Unfortunately, the resolution power of the CT scan was not sufficient to unambiguously 
identify the second attachment site of these muscle fibers. However, we assume that they correspond to the M. ampulloaorticus found in other insects.

This variability of the antennal heart construction within the Embioptera is of particular interest for the intraordinal relationships as well as for the reconstruction of the ground pattern of the Eukinolabia, respectively, other parts of the polyneopteran clade.

Intraordinal relationships of Embioptera are a subject rarely tackled and have been addressed in detail only by Szumik et al. (2008) and Miller et al. (2012). Both studies used morphological and molecular data but resulted in very different phylogenies, particularly with regard to the early splits of Embioptera. Szumik et al. (2008) used the Clothodidae, an embiopteran subgroup which is believed to possess many plesiomorphic characters, to root the tree in their analyses. Miller et al. (2012), whose study is mainly based on extensive molecular data, remarkably retrieved completely different topologies within Embioptera when treating an identical data set with different methodological approaches: parsimony analyses recovered Clothodidae (which includes Antipalura examined in the present study) as sister group to the remaining embiopterans, likelihood analyses proposed Tetraembiidae + Oligotomidae (which includes Oligotoma examined in the present study) as early branch and Bayesian analyses suggest Australembiidae (which includes Metoligotoma examined in the present study). The transcriptomic analysis of Wipfler et al. (2019) comprises five species of Embioptera including the clothodid Antipalura, which appeared in the results as sister group to all other taxa (Australembiidae were not included in this study). A detailed morphological analysis of female genitalic characters reports several characters that favour Metoligotoma as sister to the remaining Embioptera. However, no support was found for the view that the Clothodidae are the sister group of all other Embioptera (Klass and Ulbricht 2009). This is in line with our results about the antennal hearts. Outgroup comparison with Phasmatodea indicates that the condition of Metoligotoma with an antennal heart having a M. interampullaris (most likely together with a M. ampulloaorticus) is the plesiomorphic character state in Embioptera. This supports the hypothesis that Australembiidae are the sister group of the remaining Embioptera. Furthermore, it is obvious to assume that this condition is the ground pattern of Eukinolabia.

Among the remaining polyneopterans, an antennal heart with a nearly identical morphology comprising a M. interampullaris (0ah1) and a M. ampulloaorticus (0ah2) is found in Zoraptera (Wipfler and Pass 2014), Dictyoptera, i.e., mantises (Mantodea) and cockroaches plus termites (Blattodea), and in some Orthopthera (Pass 1985, 1991; Wipfler et al. 2012, 2016). The only difference concerns the antennal vessels, which in Dictyoptera have two different sections: the basal part in the head is convoluted and has a two-layered wall with an inner transport epithelium, while the distal part in the antennae has a one-layer wall epithelium without any specific organelle equipment (Pass 1985).

The occurrence of a $\mathrm{M}$. interampullaris plus a $\mathrm{M}$. ampulloaorticus in Zoraptera, Orthoptera, and Dictypotera suggests that this character state may be an older ground pattern of polyneopteran insects, but further research is needed to reconstruct the evolutionary morphology of the antennal hearts among this clade. An antennal heart with a M. ampullofrontalis, as found in all examined webspinners except Metoligotoma, is then a derived character state. Such a condition is unique among insects and obviously an autapomorphy of a part of the embiopteran clade. Regarding the evolutionary origin of the M. ampullofrontalis, we assume that it developed through the displacement of some muscle fibers of the $\mathrm{M}$ interampullaris from the attachment on the wall of the opposite ampulla to the medial area of the frontal cuticle. As a result, each ampulla has become its own dilator muscle.

Acknowledgements We thank Jannice Edgerly-Rooks (Santa Clara, USA) for providing several embiopteran specimens. $\mu$-CT measurements were carried out at BAMline at Helmholtz-Zentrum Berlin and the Deutsches Elektronen-Synchrotron (DESY; proposal I-20150409), which the authors greatly appreciate.

Funding Open Access funding enabled and organized by Projekt DEAL.

Open Access This article is licensed under a Creative Commons Attribution 4.0 International License, which permits use, sharing, adaptation, distribution and reproduction in any medium or format, as long as you give appropriate credit to the original author(s) and the source, provide a link to the Creative Commons licence, and indicate if changes were made. The images or other third party material in this article are included in the article's Creative Commons licence, unless indicated otherwise in a credit line to the material. If material is not included in the article's Creative Commons licence and your intended use is not permitted by statutory regulation or exceeds the permitted use, you will need to obtain permission directly from the copyright holder. To view a copy of this licence, visit http://creativecommons.org/licenses/by/4.0/.

\section{References}

Antemann V, Pass G, Pflüger H-J (2018) Octopaminergic innervation and a neurohaemal release site in the antennal heart of the locust Schistocerca gregaria. J Comp Physiol A 204:131-143

Barth R (1954) Untersuchungen an den Tarsaldrüsen von Embolyntha batesi McLachlan, 1877 (Embiodea). Zool Jahrb 74:172-188

Baum E, Hertel W, Beutel RG (2007) Head capsule, chephalic central nervous system and head circulatory system of an aberrant orthopteran, Prosarthria teretrirostris (Caelifera, Hexapoda). Zoology (jena) 110:147-160. https://doi.org/10.1016/j.zool.2006.10.002

Bäumler F, Koehnsen A, Tramsen HT, Gorb SN, Büsse S (2020) Illuminating nature's beauty: modular, scalable and low-cost LED dome illumination system using 3D-printing technology. Sci Rep 10:1-12 
Beutel RG, Gorb SN (2006) A revised interpretation of the evolution of attachment structures in Hexapoda with special emphasis on Mantophasmatodea. Arthropod Syst Phylogeny 64:3-25

Boppana S, Hillyer JF (2014) Hemolymph circulation in insect sensory appendages: functional mechanics of antennal accessory pulsatile organs (auxiliary hearts) in the mosquito Anopheles gambiae. J Exp Biol 217:3006-3014

Bradler S (2009) Die Phylogenie der Stab-und Gespenstschrecken (Insecta: Phasmatodea). Species Phylogeny Evol 2:1-139

Bradler S, Cliquennois N, Buckley TR (2015) Single origin of the Mascarene stick insects: ancient radiation on sunken islands? BMC Evol Biol 15:1-10

Buckley TR, Attanayake D, Bradler S (2009) Extreme convergence in stick insect evolution: phylogenetic placement of the Lord Howe Island tree lobster. Proc R Soc Biol Sci Ser B 276:1055-1062

Büscher TH, Buckley TR, Grohmann C, Gorb SN, Bradler S (2018a) The evolution of tarsal adhesive microstructures in stick and leaf insects (Phasmatodea). Front Ecol Evol 6:69

Büscher TH, Kryuchkov M, Katanaev VL, Gorb SN (2018b) Versatility of Turing patterns potentiates rapid evolution in tarsal attachment microstructures of stick and leaf insects (Phasmatodea). J R Soc Interface 15:20180281

Büsse S, Büscher TH, Taylor ET, Heepe L, Edgerly JS, Gorb SN (2019) Pressure-induced silk spinning mechanism in webspinners (Insecta: Embioptera). Soft Matter 15(47):9742-9750. https://doi. org/10.1039/C9SM01782H

Büsse S, Hörnschemeyer T, Hohu K, McMillan D, Edgerly JS (2015) The spinning apparatus of webspinners-functional-morphology, morphometrics and spinning behaviour. Sci Rep 5:1-9

Edgerly JS (1994) Is group living an antipredator defense in a facultatively communal webspinner (Embiidina: Clothodidae)? J Insect Behav 7:135-147

Edgerly JS (1997) Life beneath silk walls: a review of the primitively social Embiidina. In: Choe JC, Crespi BJ (eds) The evolution of social behavior in insects and arachnids. Cambridge University Press, Cambridge, pp 14-25

Edgerly J, Davilla J, Schoenfeld N (2002) Silk spinning behavior and domicile construction in webspinners. J Insect Behav $15: 219-242$

Edgerly JS, Büsse S, Hörnschemeyer T (2012) Spinning behaviour and morphology of the spinning glands in male and female Aposthonia ceylonica (Enderlein, 1912)(Embioptera: Oligotomidae). Zool Anz 251:297-306

Friedemann K, Wipfler B, Bradler S, Beutel RG (2012) On the head morphology of Phyllium and the phylogenetic relationships of Phasmatodea (Insecta). Acta Zool-Stockholm 93:184-199. https://doi.org/10.1111/j.1463-6395.2010.00497.x

Gereben-Krenn B-A, Pass G (1999) Circulatory organs of Diplura (Hexapoda): the basic design in Hexapoda? Int J Insect Morphol Embryol 28:71-79

Goldberg J, Bresseel J, Constant J, Kneubühler B, Leubner F, Michalik P, Bradler S (2015) Extreme convergence in egg-laying strategy across insect orders. Sci Rep 5:1-7

Grimaldi D, Engel MS (2005) Evolution of the insects. Cambridge University Press, New York, NY

Haas F, Kukalová-Peck J (2001) Dermaptera hindwing structure and folding: new evidence for familial, ordinal and superordinal relationships within Neoptera (Insecta). Eur J Entomol 98:445-510

Hennig W (1969) Die Stammesgeschichte der Insekten, vol 49. Kramer, Frankfurt

Hertel W, Pass G (2002) An evolutionary treatment of the morphology and physiology of circulatory organs in insects. Comp Biochem Physiol A 133:555-575
Hertel W, Pass G, Penzlin H (1985) Electrophysiological investigation of the antennal heart of Periplaneta americana and its reactions to proctolin. J Insect Physiol 31:563-572

Hertel W, Rapus J, Richter M, Eckert M, Vettermann S, Penzlin H (1997) The proctolinergic control of the antenna-heart in Periplaneta americana (L). Zoology 100:70-79

Hertel W, Neupert S, Eckert M (2012) Proctolin in the antennal circulatory system of lower Neoptera: a comparative pharmacological and immunohistochemical study. Physiol Entomol 37:160-170

Hillyer JF, Pass G (2020) The insect circulatory system: structure, function, and evolution. Annu Rev Entomol 65:121-143

Ishiwata K, Sasaki G, Ogawa J, Miyata T, Su Z-H (2011) Phylogenetic relationships among insect orders based on three nuclear proteincoding gene sequences. Mol Phylogenet Evol 58:169-180

Jones JC (1977) The circulatory system of insects. Thomas, Springfield, MA

Klass K-D, Ulbricht J (2009) The female genitalic region and gonoducts of Embioptera (Insecta), with general discussions on female genitalia in insects. Org Divers Evol 9:115-154

Kristensen NP (1991) Phylogeny of insect orders. Annu Rev Entomol 26:135-157

Letsch H, Simon S (2013) Insect phylogenomics: new insights on the relationships of lower neopteran orders (Polyneoptera). Syst Entomol 38:783-793

Letsch HO, Meusemann K, Wipfler B, Schutte K, Beutel R, Misof B (2012) Insect phylogenomics: results, problems and the impact of matrix composition. P Roy Soc B-Biol Sci 279:3282-3290. https://doi.org/10.1098/rspb.2012.0744

Matsumura Y et al (2015) Cephalic anatomy of Zorotypus weidneri New, 1978: new evidence for a placement of Zoraptera. Arthropod Syst Phylo 73:85-105

Miller T (1985) Structure and physiology of the circulatory system. In: Kerkut G, Gilbert L (eds) Comprehensive insect physiology, biochemistry and pharmacology, vol 3. Pergamon, Oxford, pp 289-355

Miller TA, Pass G (2009) Circulatory system. In: Resh VH, Carde R (eds) Encyclopedia of insects. Academic Press, Massachusetts, pp 169-173

Miller KB, Hayashi C, Whiting MF, Svenson GJ, Edgerly JS (2012) The phylogeny and classification of Embioptera (Insecta). Syst Entomol 37:550-570

Misof B et al (2014) Phylogenomics resolves the timing and pattern of insect evolution. Science 346:763-767. https://doi.org/10.1126/ science. 1257570

O'Hanlon JC, Jones BR, Bulbert MW (2020) The dynamic eggs of the Phasmatodea and their apparent convergence with plants. Sci Nat 107:1-12

Pass G (1980) The anatomy and ultrastructure of the antennal circulatory organs in the cockchafer beetle Melolontha melolontha $\mathrm{L}$. (Coleoptera, Scarabaeidae). Zoomorphology 96:77-89

Pass G (1985) Gross and fine structure of the antennal circulatory organ in cockroaches (Blattodea, Insecta). J Morphol 185:255-268

Pass G (1988) Functional morphology and evolutionary aspects of unusual antennal circulatory organs in Labidura riparia Pallas (Labiduridae), Forficula auricularia L. and Chelidurella acanthopygia Gene (Forficulidae) (Insecta: Dermaptera). Int J Insect Morphol Embryol 17:103-112

Pass G (1991) Antennal circulatory organs in Onychophora, Myriapoda and Hexapoda: functional morphology and evolutionary implications. Zoomorphology 110:145-164

Pass G (1998) Accessory pulsatile organs. Mic Ana Inver 11:621-640

Pass G (2000) Accessory pulsatile organs: evolutionary innovations in insects. Annu Rev Entomol 45:495-518

Pass G, Agricola H, Birkenbeil H, Penzlin H (1988) Morphology of neurones associated with the antennal heart of Periplaneta americana (Blattodea, Insecta). Cell Tis Res 253:319-326 
Pass G, Gereben-Krenn B-A, Merl M, Plant J, Szucsich NU, Tögel M (2006) Phylogenetic relationships of the orders of Hexapoda: contributions from the circulatory organs for a morphological data matrix. Arthropod Syst Phylo 64:165-203

Pass G, Tögel M, Krenn H, Paululat A (2015) The circulatory organs of insect wings: Prime examples for the origin of evolutionary novelties. Zoologischer Anzeiger - J Comp Zool 256:82-95. https://doi. org/10.1016/j.jcz.2015.03.008

Pawlowa M (1895) Über ampullenartige Blutcirculationsorgane im Kopfe verschiedener Orthopteren. Zool Anz 18:7-13

Rähle W (1970) Untersuchungen an Kopf und Prothorax von Embia ramburi Rimsky-Korsakow 1906 Embioptera, Embiidae. Zool Jahrb Abt Anat Ontog Tiere 87:248-330

Raina A, Meola S, Wergin W, Blackburn M, Bali G (2003) Antennal ampullary glands of Helicoverpa zea (Lepidoptera: Noctuidae). Cell Tis Res 312:127-134

Ross ES (2000) Embia: Contributions to the biosystematics of the insect order Embiidina. Part 1, Origin, relationships and integumental anatomy of the insect order Embiidina. Part 2. A review of the biology of Embiidina. Occas Pap Calif Acad Sci 149:1-53

Scholl G (1969) Die Embryonalentwicklung des Kopfes und Prothorax von Carausius morosus Br. (Insecta, Phasmida). Zeit Morph Tier $65: 1-142$

Seifert G (1970) Entomologisches Praktikum. Georg Thieme Verlag, Stuttgart

Simon S et al (2019) Old World and New World Phasmatodea: phylogenomics resolve the evolutionary history of stick and leaf insects. Front Ecol Evol 7:345

Stokes GY et al (2018) Structural and wetting properties of nature's finest silks (order Embioptera). Royal Soc Open Sci 5:180893

Sun B, Schmidt J (1997) The structure of the antennal heart of Aedes aegypti (Linnaeus). Can J Zool 75:444-458

Szumik C, Edgerly JS, Hayashi CY (2008) Phylogeny of embiopterans (Insecta). Cladistics 24:993-1005

Terry MD, Whiting MF (2005) Mantophasmatodea and phylogeny of the lower neopterous insects. Cladistics 21:240-257

Whiting MF, Bradler S, Maxwell T (2003) Loss and recovery of wings in stick insects. Nature 421:264-267
Wipfler B, Pass G (2014) Antennal heart morphology supports relationship of Zoraptera with polyneopteran insects. Syst Entomol 39:800-805

Wipfler B, Machida R, Muller B, Beutel RG (2011) On the head morphology of Grylloblattodea (Insecta) and the systematic position of the order, with a new nomenclature for the head muscles of Dicondylia. Syst Entomol 36:241-266. https://doi.org/10.1111/j. 1365-3113.2010.00556.x

Wipfler B, Wieland F, DeCarlo F, Hornschemeyer T (2012) Cephalic morphology of Hymenopus coronatus (Insecta: Mantodea) and its phylogenetic implications. Arthropod Struct Dev 41:87-100. https://doi.org/10.1016/j.asd.2011.06.005

Wipfler B, Weissing K, Klass KD, Weihmann T (2016) The cephalic morphology of the American cockroach Periplaneta americana (Blattodea). Arthropod Syst Phylogeny 74:267-297

Wipfler B et al (2019) Evolutionary history of Polyneoptera and its implications for our understanding of early winged insects. Proc Natl Acad Sci USA 116:3024-3029

Wirkner CS, Richter S (2010) Evolutionary morphology of the circulatory system in Peracarida (Malacostraca; Crustacea). Cladistics 26:143-167

Wirkner CS, Tögel M, Pass G (2013) The arthropod circulatory system. In: Minelli A, Boxshal G, Fusco G (eds) Arthropod biology and evolution. Springer, Heidelberg, pp 343-391

Zacharuk R (1985) Antennae and sensilla. In: Kerkut G, Gilbert L (eds) Comprehensive insect physiology biochemistry and pharmacology. VI. Nervous system: sensory. Pergamon Press, London, pp $1-69$

Zeng Y, O'Malley C, Singhal S, Rahim F, Park S, Chen X, Dudley R (2020) A tale of winglets: evolution of flight morphology in stick insects. Front Ecol Evol 8:121

Publisher's Note Springer Nature remains neutral with regard to jurisdictional claims in published maps and institutional affiliations. 